\title{
Household Financial Situation during the COVID-19 Pandemic with Particular Emphasis on Savings-An Evidence from Poland Compared to Other CEE States
}

\author{
Grażyna Szustak, Witold Gradoń and Łukasz Szewczyk *10
}

Citation: Szustak, Grażyna, Witold Gradoń, and Łukasz Szewczyk. 2021. Household Financial Situation during the COVID-19 Pandemic with Particular Emphasis on Savings-An Evidence from Poland Compared to Other CEE States. Risks 9: 166.

https://doi.org/10.3390/risks9090166

Academic Editor: Mogens Steffensen

Received: 8 July 2021

Accepted: 7 September 2021

Published: 12 September 2021

Publisher's Note: MDPI stays neutral with regard to jurisdictional claims in published maps and institutional affiliations.

Copyright: (c) 2021 by the authors. Licensee MDPI, Basel, Switzerland. This article is an open access article distributed under the terms and conditions of the Creative Commons Attribution (CC BY) license (https:/ / creativecommons.org/licenses/by/ $4.0 /)$.
Department of Banking and Financial Markets, University of Economics in Katowice, 40-287 Katowice, Poland; grazyna.szustak@uekat.pl (G.S.); witold.gradon@uekat.pl (W.G.)

* Correspondence: lukasz.szewczyk@uekat.pl

Abstract: The aim of this article is to analyze and assess the impact of the pandemic on the finances of households in Poland, compared to other CEE countries (including Czech Republic, Slovakia and Hungary), with particular emphasis on changes in the level of their savings, which are considered to be the foundation for the development of the indicated research group. There is no doubt that the pandemic had an impact on the situation of households, which is mainly visible in the labor market (rising unemployment), and thus the question arises to what extent have the households' approaches to financial decisions changed because of this situation? The propensity to save was taken into account as a main aspect of this problem, because it has, among others, a big impact on the financial well-being (in a broader sense). Using the multiple linear regression method, the factors that influence the level of household savings were determined. The results of the research show that these factors are different in the analyzed countries and have a different impact on the level of the explained variable, which is the gross saving rate. The research should also be treated as a preliminary one. It constitutes a contribution to in-depth research with the use of more sophisticated statistical and econometric methods, which will allow for the better assessment of the examined issue.

Keywords: households; COVID-19; savings; financial situation; financial well-being

\section{Introduction}

The pandemic has hugely affected the economies, and through this, the finances of households. On some of them, the impact will be temporary, but many of the consequences will probably be visible in a long-term period. A 2015 study, conducted by The Pew Charitable Trusts among US citizens, shows that in $25 \%$ of responses, the impact of a simple event (e.g., unexpected car repair) was still present 6 months after the incident. The shock effect was longest for those with the lowest resources. It can also be read in the article that financial shocks have long-term effects, regardless of the level of household income, while the financial shock weakens the sense of financial security in households. The shock of a pandemic is obviously the least damaging to people with a high level of liquid savings or jobs that could be transferred to a virtual environment (Fox and Bartholomae 2020). An important question arises here. What level of savings can be considered sufficient? Of course, the answer is not easy. Brobeck (2008) proposes a concept of emergency savings, defining them as a "the gap between unexpected routine expenditures and funds from transaction accounts, especially savings accounts, that was readily available to pay for these expenditures".

In this particular context, it is commonly believed that periods of economic crises are usually accompanied by an increase in the level of household savings. It should be noted, however, that these savings are of a distinctly different nature than in periods of economic growth. They mainly result from the use of cost and expenditure reduction strategies by 
households in order to survive the difficult and uncertain period caused by the crisis. The increase in the level of savings is therefore due to precautionary reasons.

The case of the pandemic that broke out in 2020 prompts the authors of this article to investigate what the factors are that had the greatest impact on the level of savings in the turbulent times of the crisis. It should be noted that among the factors that distinguish the period of the pandemic from other crisis periods are the effects of temporarily introduced lockdowns (hard or soft), which result in the forced reduction of consumer demand and a clear decrease in orders of products and services. The introduction of trade restrictions has also obviously reduced the scale of impulse consumption. Savings created during the crisis, which is the pandemic, could therefore result both from precautionary reasons, and could also have the nature of forced savings. It should also not be forgotten that lockdown can result in the loss of jobs or a reduction in salaries for many people, so that their savings level can drop rapidly and their savings can be even lost entirely.

On the other hand, evidence suggests that credit markets have tightened and it may be more difficult for consumers to access new credit now than before the pandemic (Cooper et al. 2020). It is also worth taking into account the fact that households themselves, fearing a difficult situation in the future, are less willing to incur liabilities. From the bank's perspective, the potential increase in the share of non-performing loans in portfolios may be worrying, because it may have long-term consequences for them.

The aim of the article is therefore to analyze and finally assess the impact of the pandemic on the finances of households in Poland, compared to other CEE countries, with particular emphasis on changes in the level of their savings, which are considered to be the foundation for the financial well-being of the indicated research group.

Central and Eastern European countries were selected for the study due to the fact that they are at a similar level of development.

\section{The Course of COVID-19 Pandemic and Its Relation to the Economy}

Outbreaks can be caused by new or recurring infectious diseases. Among the most recognizable are the epidemics of AIDS, SARS, MERS and finally COVID-19. Epidemics are governed by certain laws relating to their formation and development. These include issues related to the density of the population, the increase in population immunity, the method of infection and the effectiveness of the organism's (immune) response (Glinski and Żmuda 2020, p. 557). The coronavirus pandemic undoubtedly fits this model.

The coronavirus pandemic, one of the largest and most severe epidemics in human history, began in 2019. It is assumed that its focus was the Chinese city of Wuhan, where the virus was diagnosed in the first person. In the first phase, it was China that was most affected by the effects of the spread of the virus, which meant that at the beginning of 2020, the virus was identified as a new type of pathogen causing the COVID-19 disease (Marcinkowska 2020, p. 15). The virus began to spread rapidly, and already in February 2020, the first peak in the number of cases in this country was recorded, with the number of patients exceeding 15,000 new cases during the day. Due to the rapid spread of the virus, the World Health Organization announced a coronavirus pandemic in March 2020 (WHO Announces a Pandemic 2020). Cases of the coronavirus have been reported in virtually all countries of the world, but the number of cases (including fatalities) varied. It resulted, inter alia, from different country-specific restrictions and the level of efficiency of the health system. In Poland, the epidemic was introduced on 20 March 2020 by the Regulation of the Minister of Health (Rozporządzenie Ministra Zdrowia 2020). It is worth emphasizing that by mid-March 2020, approx. 30\% of cases were people who became infected abroad (Duszyński et al. 2020, p. 14). Later, this share naturally began to drop significantly. The effect of the spread of the virus was the introduction of a number of restrictions aimed at stopping this trend and at the same time preventing a situation in which there would be a loss in the efficiency of the health care system. It should be emphasized here that the nature of the restrictions and their scale varied from country to country. A relatively liberal policy in this area was pursued by, for example, Sweden, where the obligation to wear masks was 
not introduced, restaurants remained open and stationary education continued in schools. There, however, policy makers had a liberal approach to restrictions, and it is believed the lack of restrictions contributed to a relatively high number of deaths (which is undoubtedly the effect of a high number of cases per 100,000 inhabitants, amounting to 600).

It should also be emphasized that the current crisis is often compared with the Spanish pandemic that broke out in 1918 and the SARS epidemic. These comparisons are naturally given by the source (i.e., pathogen) and the fact that they have had a specific economic impact. Undoubtedly, there are easily noticeable differences between them, which make each of them unique. A comparison of crisis experiences in this area is presented in Table 1.

Table 1. The Spanish flu, SARS epidemic and COVID-19 pandemic-common points and fundamental differences.

\begin{tabular}{|c|c|c|}
\hline & The Spanish Flu & SARS \\
\hline Similarities to COVID-19 & $\begin{array}{l}\text { High mortality, external shock } \\
\text { difficult to predict } \\
\text { It spread practically all over } \\
\text { the world } \\
\text { Application of the lockdown } \\
\text { strategy }\end{array}$ & $\begin{array}{l}\text { Similar channels of influence } \\
\text { Source of the } \\
\text { epidemic-China }\end{array}$ \\
\hline Main differences & $\begin{array}{l}\text { Less importance of the service } \\
\text { sector in economies } \\
\text { It mainly killed young people } \\
\text { Consequences of the } \\
\text { pandemic compounded by } \\
\text { war losses } \\
\text { Less interdependence } \\
\text { between economies }\end{array}$ & $\begin{array}{l}\text { A smaller scale of } \\
\text { disturbances in the economy } \\
\text { Different nature of } \\
\text { international ties }\end{array}$ \\
\hline
\end{tabular}

Source: (Grzeszak et al. 2020, pp. 20-22).

F. Boissay, D. Rees and P. Rungcharoenkitkul point out that in the face of the coronavirus pandemic, the world found itself in a situation where economies had to be virtually shut down in order to limit the effects of the health crisis. They indicate three key issues in this area (Boissay et al. 2020):

- The policy of closing economies saves human lives, but significantly reduces economic activity, and thus generates specific economic costs,

- Integrated epidemic and macroeconomic models provide a coherent framework for quantifying the costs and benefits of a policy to foreclose economies. Some of the benefits result from limiting the externalities that would arise if social distancing was voluntary,

- Policies with a lockdown of up to $30 \%$ of GDP may be preferred over an alternative with more casualties and a less severe recession.

It is worth mentioning that the COVID-19 pandemic affects the economy through the following channels (Raport Banku Pekao 2020):

- A significant drop in demand, which is primarily a consequence of restrictions in movement (both on a national and international scale),

- Disruptions in the supply chain (import of raw materials, semi-finished products, finished products), which is felt both nationally and internationally,

- Downtime caused by the suspension of the activity of some industries (e.g., catering, hotel, commercial), resulting from the introduced restrictions and infection of the staff,

- Unfavorable price changes,

- Significant deterioration of the financial situation of companies, as a consequence of the epidemic, as well as of their employees. 
Researchers form the Polish Economic Institute presented a slightly different approach. They distinguished four channels in which the crisis impacts the economy, i.e., the supply and demand channels, public mood and the broadly understood financial system (Table 2).

Table 2. Channels of impact of the COVID-19 crisis on the economy.

\begin{tabular}{cl}
\hline An Area of Influence & \multicolumn{1}{c}{ Characteristics } \\
\hline Supply channel & Lack of staff \\
& Lack of resources \\
\hline \multirow{2}{*}{ Demand channel } & Consumption drop \\
& Private investment decline \\
& Breakdown in selected sectors \\
\hline Social moods & Decline in consumer and business confidence \\
& Investors panic in the financial markets \\
\hline \multirow{2}{*}{ Financial system } & Declines in the prices of financial assets \\
& Increase in risk aversion \\
& Credit availability decline \\
& Increase in non-performing loans \\
& Liquidity decline \\
& Decline in the stability of the financial system \\
\hline
\end{tabular}

Source: (Grzeszak et al. 2020, p. 9).

It should be emphasized that the problem of the impact of the COVID-19 epidemic on the economy is analyzed in an increasing number of scientific publications. This also applies to the issue of the impact of the pandemic on households in various areas. R. Chetty in his research indicates that the pandemic had a large impact on high-income households whose members were more likely to go into isolation and thus reduced spending in those sectors that required physical contact (Chetty et al. 2020, p. 40). Ł. Kurowski emphasizes, however, that the pandemic crisis drew particular attention to the need to prepare households for unexpected loss of income. This is mainly due to the fact that virtually no economic model has allowed us to predict the moment when the pandemic will hit the economy with a consequence comparable to that of the global crisis of 2007-2009. The research shows that there is a relationship between financial knowledge and the financial situation, which may be caused by the impact of the health crisis. People with greater financial knowledge tend to have higher savings, but are also more concerned about their financial situation. They also have a lower level of excessive debt (Kurowski 2021, p. 12).

The extent to which households are able to survive crisis situations depends primarily on (Bilyk et al. 2020):

- Financial condition of households when the shock started,

- Effectiveness of political actions aimed at improving the financial situation of households,

- The speed with which the recovery in the labor market occurs.

M. Marcinkowska divided the instruments aimed at limiting the negative effects of the crisis into four basic groups, including fiscal tools, central bank instruments, instruments affecting the trade balance and regulations of financial institutions. The most extensive group of instruments are fiscal instruments, including those aimed at improving the situation of households, i.e., lowering the income tax for natural persons, various forms of benefits, or direct financial support (Marcinkowska 2020, p. 45).

On the other hand, O. Jerusalmy points out the measures that should be taken to protect the households most vulnerable to the pandemic (Jerusalmy 2020):

- Low-income households that are indebted or even over-indebted do not notice the deterioration of their financial situation during the health crisis. The measures to be taken must ensure that income levels of these households are maintained and that they prevent the increase in financial burdens (in particular those related to debt 
management). It should be noted here that low-income households most often do not have savings that would allow them to survive a difficult situation,

- Governments should take the necessary steps to support the efforts of lenders (banks and non-banking institutions) to avoid jeopardizing the stability of the financial sector,

- The use of additional debt by vulnerable households should be limited to weather the crisis in order to avoid a massive increase in over-indebtedness,

- State aid, both at the national and supranational level, must allow not only maintaining the good condition of the financial sector and the entire economy, but also the financial condition of households,

- Another interesting approach is the Spanish initiative to provide a basic income to all citizens, which will protect the most vulnerable ones.

\section{COVID-19 Pandemic and Households' Situation in Poland against the Background of Selected EU Economies}

When discussing the problem of COVID-19 impact on households, one should take into account the problem of financial well- being as a measure of so-called financial health (Barrafrem et al. 2020, p. 1). The concept of financial well-being is ambiguous. Kahneman and Krueger (2006) point out that this term is strictly subjective. Dolan et al. (2008) pay attention to the fact that there are many factors negatively associated with the financial wellbeing, e.g., unemployment and the lack of social contact. Gerrans et al. (2014) introduce a concept of financial wellness, which is defined as "a comprehensive, multidimensional concept incorporating financial satisfaction, objective status of financial situation, financial attitudes, and behavior that cannot be assessed through one measure". In this context, a model for measuring financial well-being is proposed by the Consumer Financial Protection Bureau (2015). According to it, financial well-being consists of such elements as:

- "having control over one's finance,

- having a financial cushion, which can be used against emergencies,

- having financial goals,

- being able to make choices that allow to live a happy life".

In the light of the considerations, it is necessary to mention that one of the most important issues in terms of the pandemic's influence on households is that the pandemic has contributed to the increase in unemployment in the world, and although it is not evenly distributed in individual countries and sectors, looking at the overall scale of the phenomenon, the change in this respect is significant, causing financial problems for people losing their jobs, especially when they do not have savings, and the temporary state aid for the unemployed is short-term and low. According to the World Economic Outlook published by the International Monetary Fund in October 2020, the consequences of the pandemic in terms of employment and income of citizens, especially those in a difficult financial situation, informally employed women and young people (the future income of the latter will not be favored by remote learning), will be long-term. According to the IMF, the first quarter of 2020 has a loss of 160 million jobs, the second quarter of 2020 has the loss of 495 million full-time jobs, in the third quarter, the expected decline in full-time jobs is 345 million (of which 19.8\% is in North and South America, Arab countries 12.4\%, Europe and Central Asia 11.6\%, Africa 11.5\%, Asia-Pacific 10.7\%), and 245 million in Q4 (Ventura 2020).

Interesting research in this matter on a sample from the Australian population was carried out by A. Suomi, T.P. Schofield and P. Butterworth, showing the impact of the pandemic on changes in the perception of the unemployed and economically active, pointing out that the employability and conscientiousness of the unemployed are now better assessed than before the pandemic. Therefore, the difference in the perception of the employed and the unemployed weakened to a certain extent (although the unemployed are still assessed worse than the employed), the change was due to, inter alia, an increased sense of vulnerability and awareness of the risk of losing a job (Suomi et al. 2020). 
What is the impact of unemployment on savings? It seems obvious, as the level of unemployment impacts the economy as a whole. Kłopocka (2016) shows in her research that level of unemployment is a significant factor that determines the level of household savings. In this context, savings are also associated with the concept of economic security. The employment reduction causes a decrease in the value of broadly perceived economic security (Kosny and Piotrowska 2013). Moreover, the probability of losing a job should have an effect on saving in its precautionary component (Carbone and Hey 1999).

Figure 1 presents changes in the unemployment rate in selected countries, which belong to the CEE group, including Poland. The unemployment rate in Poland showed only a slight increase, placing Poland in second place, just behind the Czech Republic, which had the lowest unemployment rate within his group. Unfortunately, as shown in Figure 2, Poland has almost the lowest percentage of job vacancies (the same level as Slovakia), with the number of vacancies still falling during the pandemic. The Czech Republic, meanwhile, has the highest level of vacancies (Anna Unton 2021).

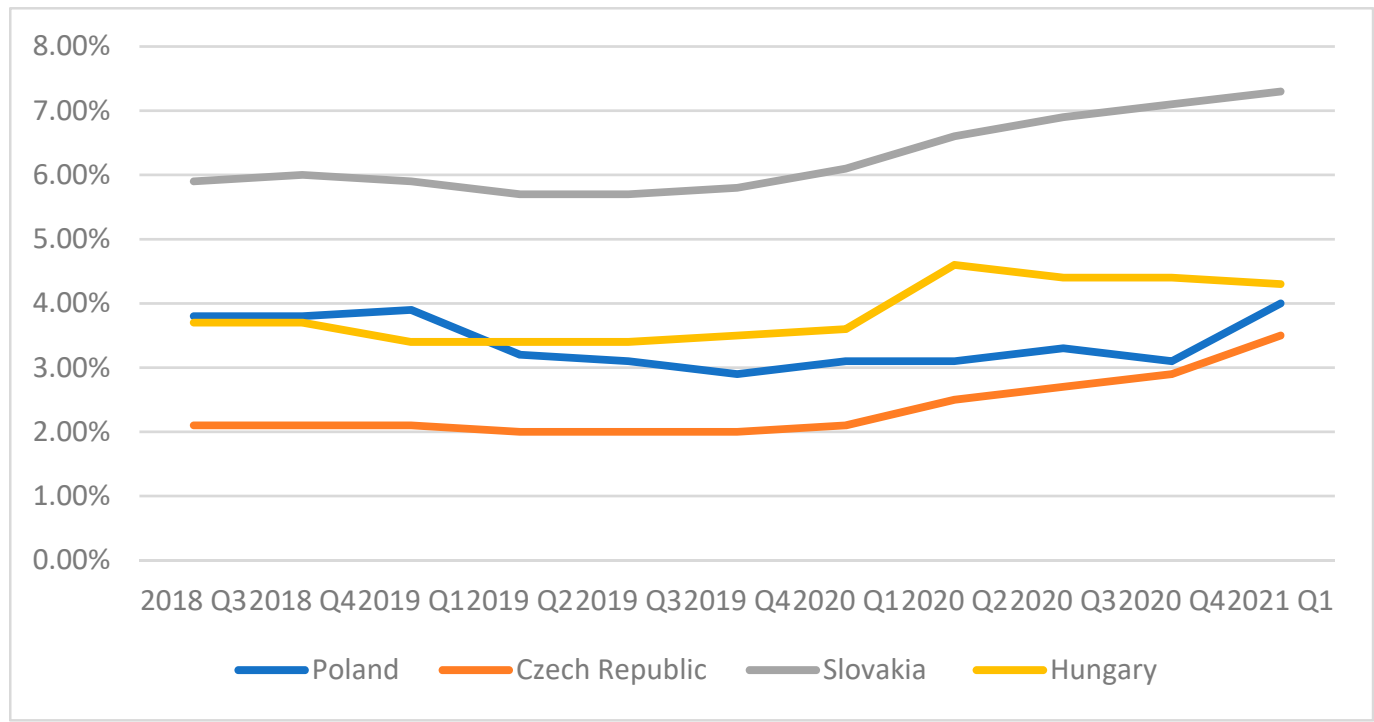

Figure 1. Unemployment rate in selected CEE countries. Source: (Eurostat Database 2021).

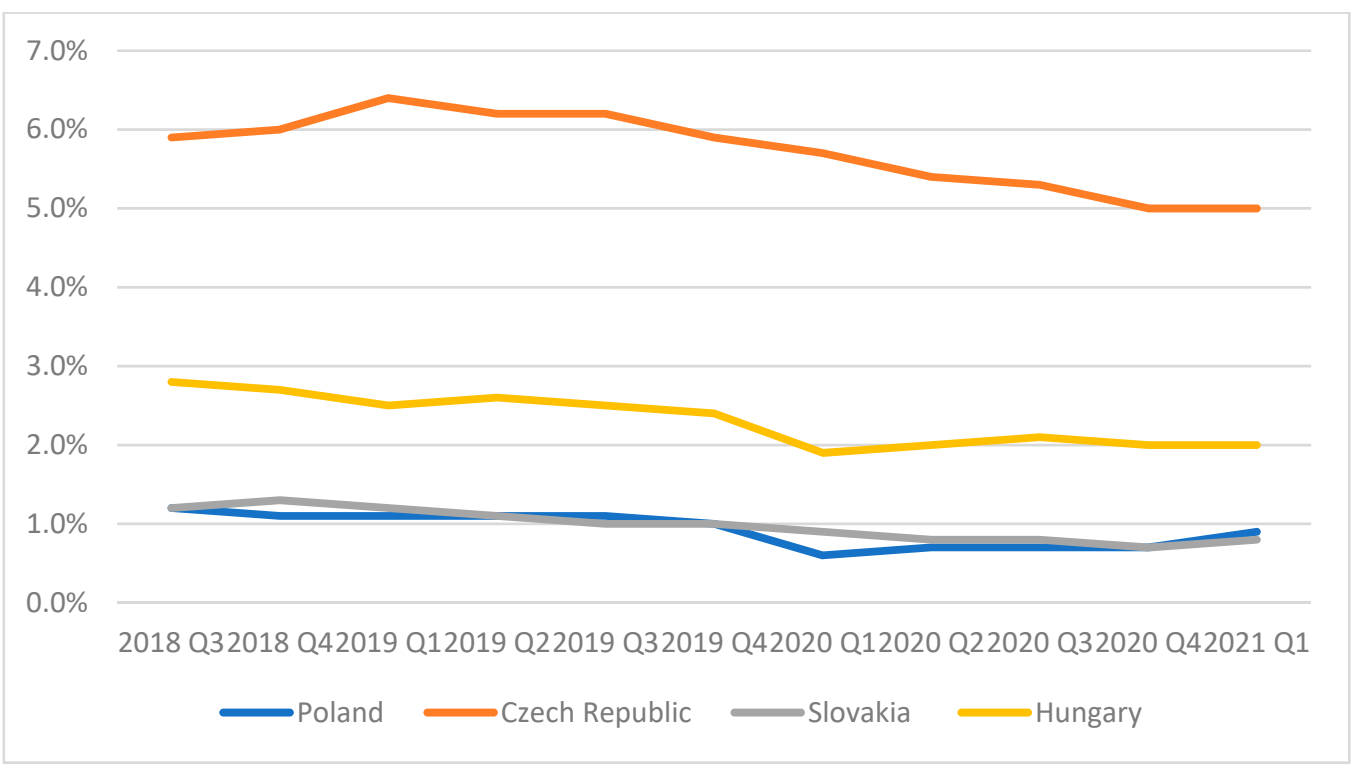

Figure 2. Job vacancy rate in selected CEE countries. Source: (Eurostat Database 2021). 
The dynamics of real gross disposable income (per capita) in Poland was positive in the considered period, although it decreased significantly in Q3 2020 (Figure 3). Against this background, Poland fares relatively well compared to the euro area, although other CEE countries have this rate higher, e.g., Czech Republic- 1.75\% in a 4th quarter of 2020 (in Poland minus $4.34 \%$ then). Unfortunately, Poles' incomes are still low, especially compared to those of Western Europe. The GfK Purchasing Power Europe 2020 report shows that the average annual income of a Pole, after deducting taxes, social security and health insurance contributions, amounts to an average of EUR 7 143. At the other extreme, there is a resident of Liechtenstein with over EUR 64 000. On average, in Europe, the annual disposable income per capita was almost EUR 13.9 thousand (there was a nominal decrease in purchasing power in 2020 by 5.3\%) (Muranyi and Richter 2020, p. 1; GfK Purchasing Power Europe 2020). It is important because research proves the positive correlation between disposable income and the level of savings (Andrejovská and Buleca 2015).

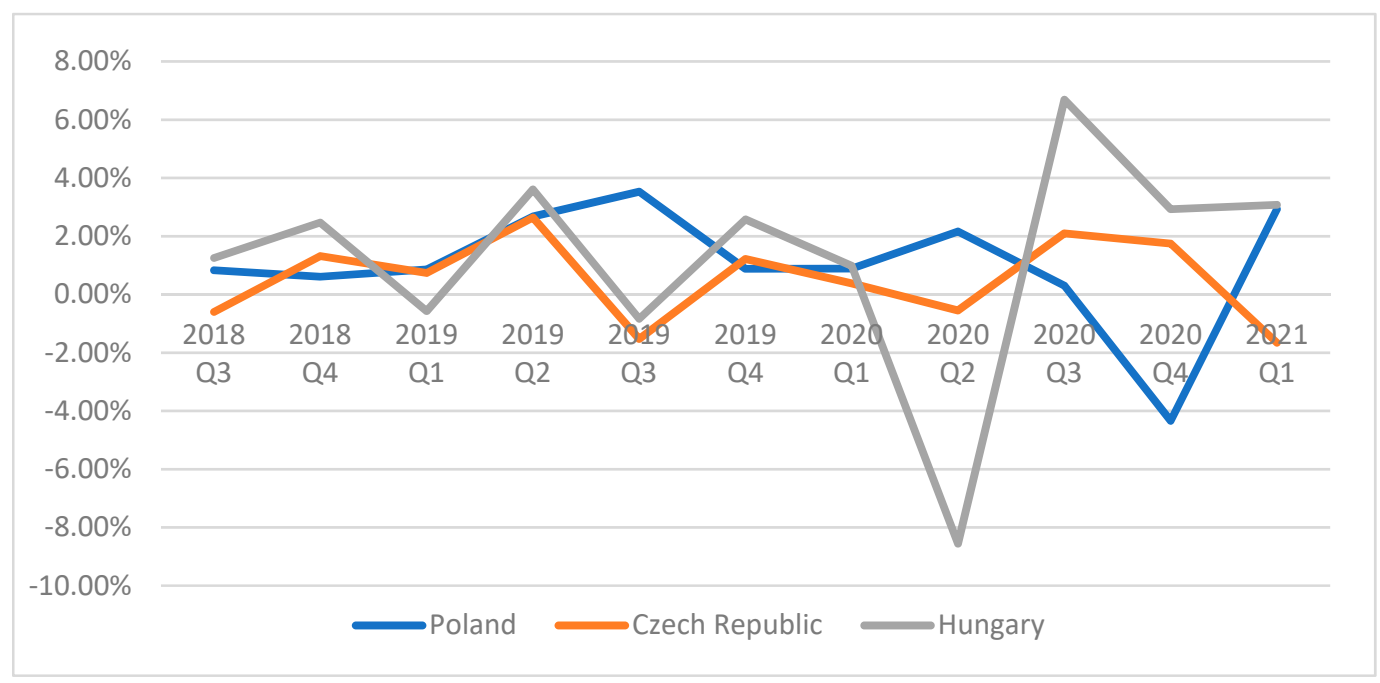

Figure 3. Household real gross disposable income (per capita) growth rate compared to previous quarter. Lack of sufficient data for Slovakia. Source: (OECD Database 2021).

It is worth mentioning that the average purchasing power index of a Pole was only $51 \%$ (Figure 4). Prices in Poland are also lower, but this does not mean that they are in line with the income difference. The average price level in Poland is $60 \%$ of the EU average. At the same time, the Corona Impact Index shows the high impact of the pandemic on the level of income of Poles, it is much higher than the European average, amounting to as much as $138 \%$, which means a decrease in the purchasing power of Polish households by 38\% (Anna Unton 2020) (Figure 4). It is worth mentioning that in Czech Republic and Hungary the situation is even worse.

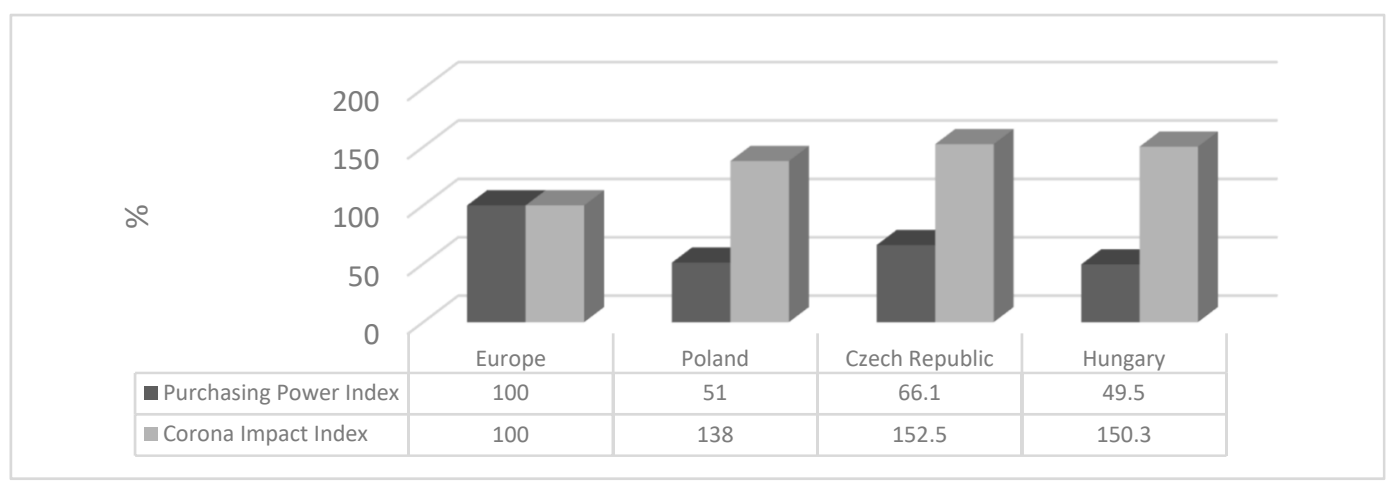

Figure 4. Purchasing Power Index and Corona Impact Index (Europe-ranking 2020). Lack of sufficient data for Slovakia. Source: (Muranyi and Richter 2020; GfK Purchasing Power Europe 2020, pp. 2-3; Anna Unton 2020). 
Loss of work and income, uncertainty of the future caused by the pandemic, increased caution translated into appreciating saving, limiting the activity of the population, lockdowns-translated into a reduction in the growth rate of consumption expenditure (Figure 5). The highest, negative dynamics appeared in the second quarter of 2020, also in Poland.

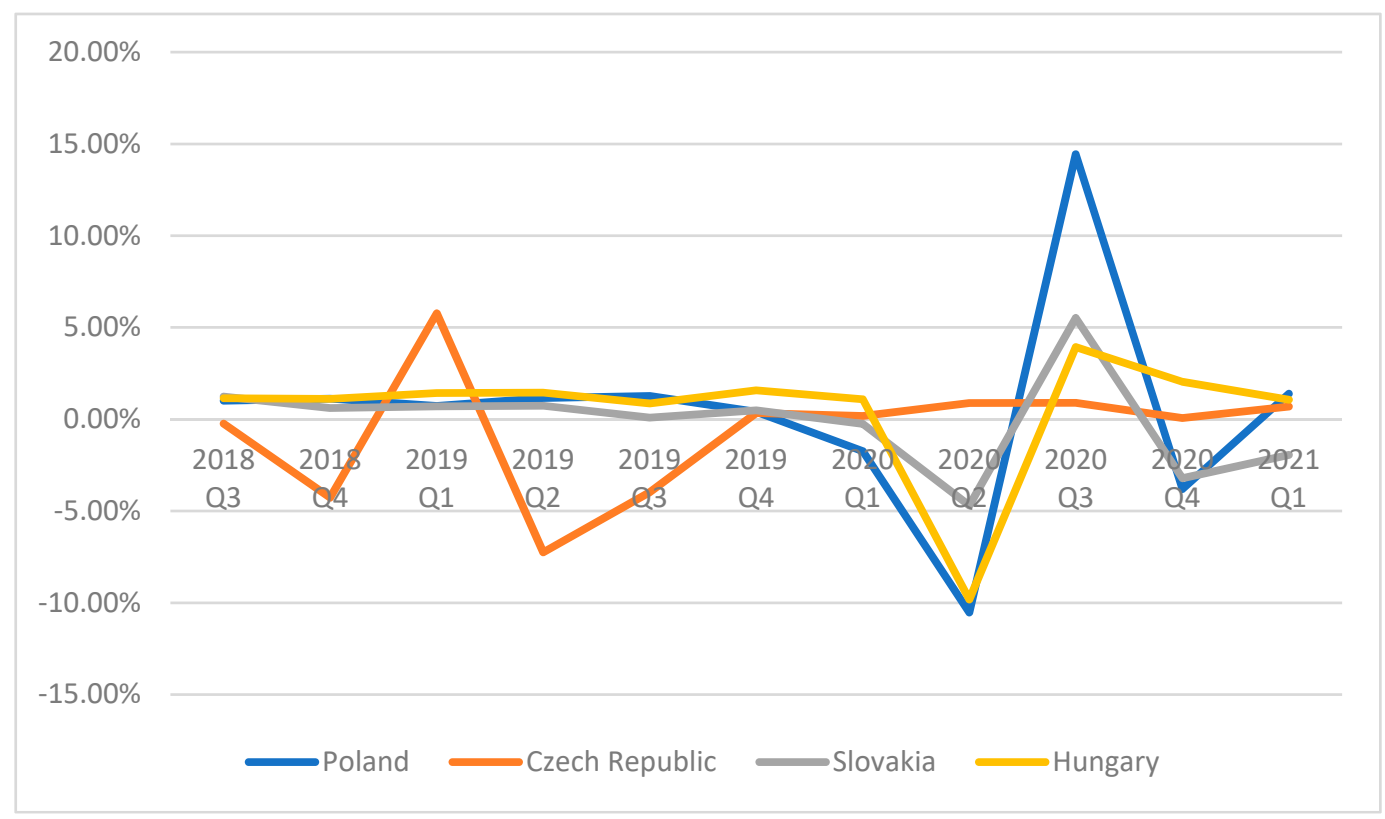

Figure 5. Household real final consumption expenditure (per capita) in selected CEE countries—growth rate compared to previous quarter. Source: (OECD Database 2021).

An important issue that can also be taken into account when assessing the household's financial situation is the Consumer Confidence Index (CCI). It measures the approach to future financial situation based upon answers regarding their expected financial situation, their sentiment about the general economic situation, unemployment and capability of savings. The results of this measure are presented on Figure 6. It can be seen that during the COVID pandemic, the CCI has fallen in three of the four analyzed countries (Hungary is an exception). Such a decrease is understandable when one takes into account the fact that the pandemic triggered a belief that the future is highly uncertain (e.g., in terms of unemployment and overall financial well-being). Moreover, Kłopocka et al. (2014) show in their research that the level of optimism (which can be assessed using CCI) is positively associated with the share of savers and the level of accumulated savings.

The analysis of the impact of the sars-cov2 virus pandemic on the level of household savings has been carried out in Poland by various institutions. One of them is ING Bank, which in mid-2020 conducted research in 13 European countries. The results prove that there were no significant changes in the average level of savings self-declared by households (these results however contradict the official data presented by European Commission). It may be, however, a consequence of the fact that questionnaire research does not always fully reflect the actual state of affairs. The number of households, among those that participated in the survey, reporting no savings remained stable $-26 \%$ in May 2020 compared to $28 \%$ in December 2019, and the average figure for the last eight years varies between $25 \%$ and $35 \%$ (Edukacjagieldowa.pl 2020). It can therefore be assumed that the pandemic did not result in a noticeable increase in the number of households that do not have any savings due to the pandemic. Research conducted by ING Bank also shows that the percentage of people declaring that they have savings in Poland has decreased from 71 to $68 \%$, and on average in Europe from 66 to 64\% (Pogorzelski 2020, p. 2). This slight decrease is most likely related to the need to infringe their savings by people who lost their job or part of their income as a result of the lockdown due to the need to cover 
the needs related to the so-called autonomous consumption. At the same time official data showed that the household saving rate in the euro area was at $17.5 \%$ in the third quarter of 2020 , compared with $25.1 \%$ in the second quarter of 2020 . At the time of the analysis, this ratio in Poland was on a very low level, comparing it to, e.g., Czech Republic or Hungary. The increase in the savings rate in Poland was short-lived (Q2 of 2020) compared to other CEE countries (Figure 7). Although the restrictions introduced in Poland were similar to those in European countries, they had a much smaller impact on financial decisions. Poles' financial decisions are influenced by the fear of inflation and the loss of value of their accumulated funds, experts believe.

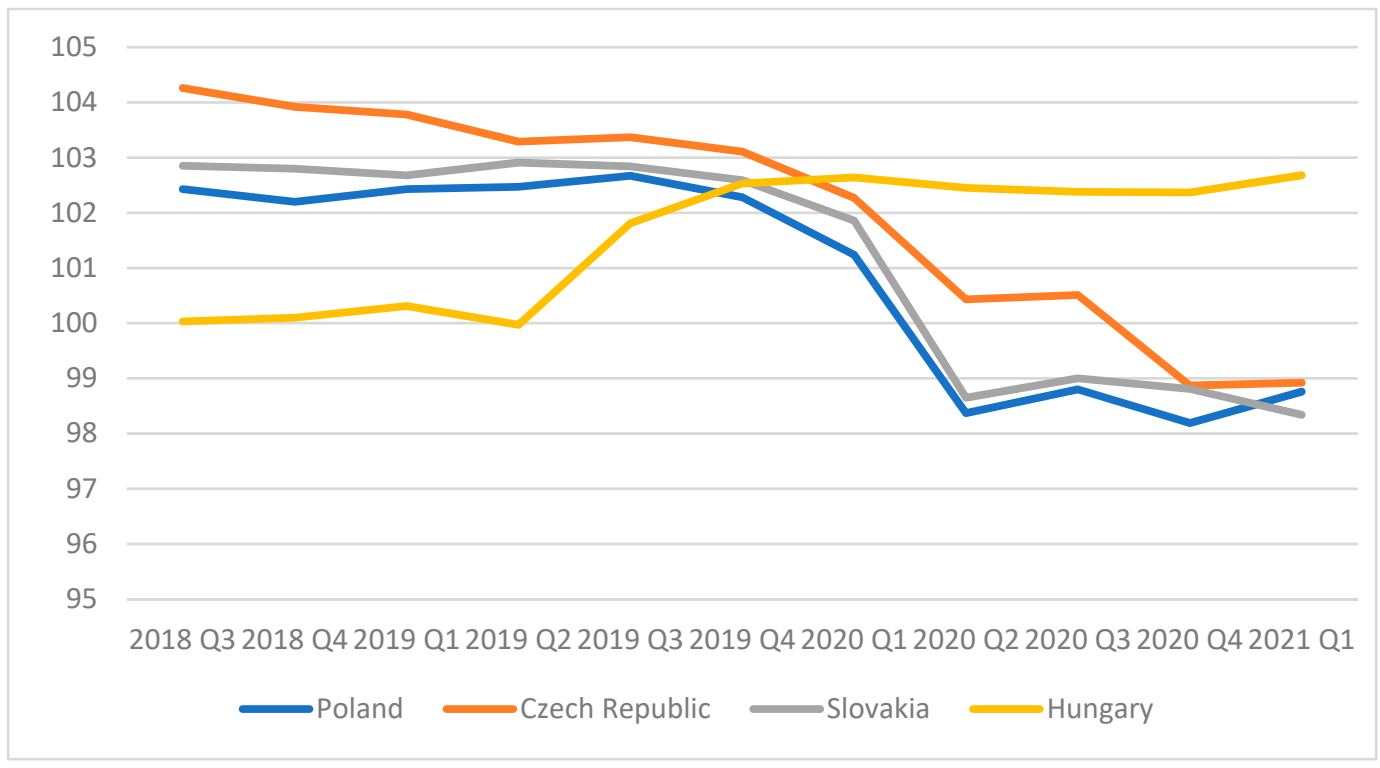

Figure 6. Consumer Confidence Index (CCI) in selected CEE states. Source: (OECD Database 2021).

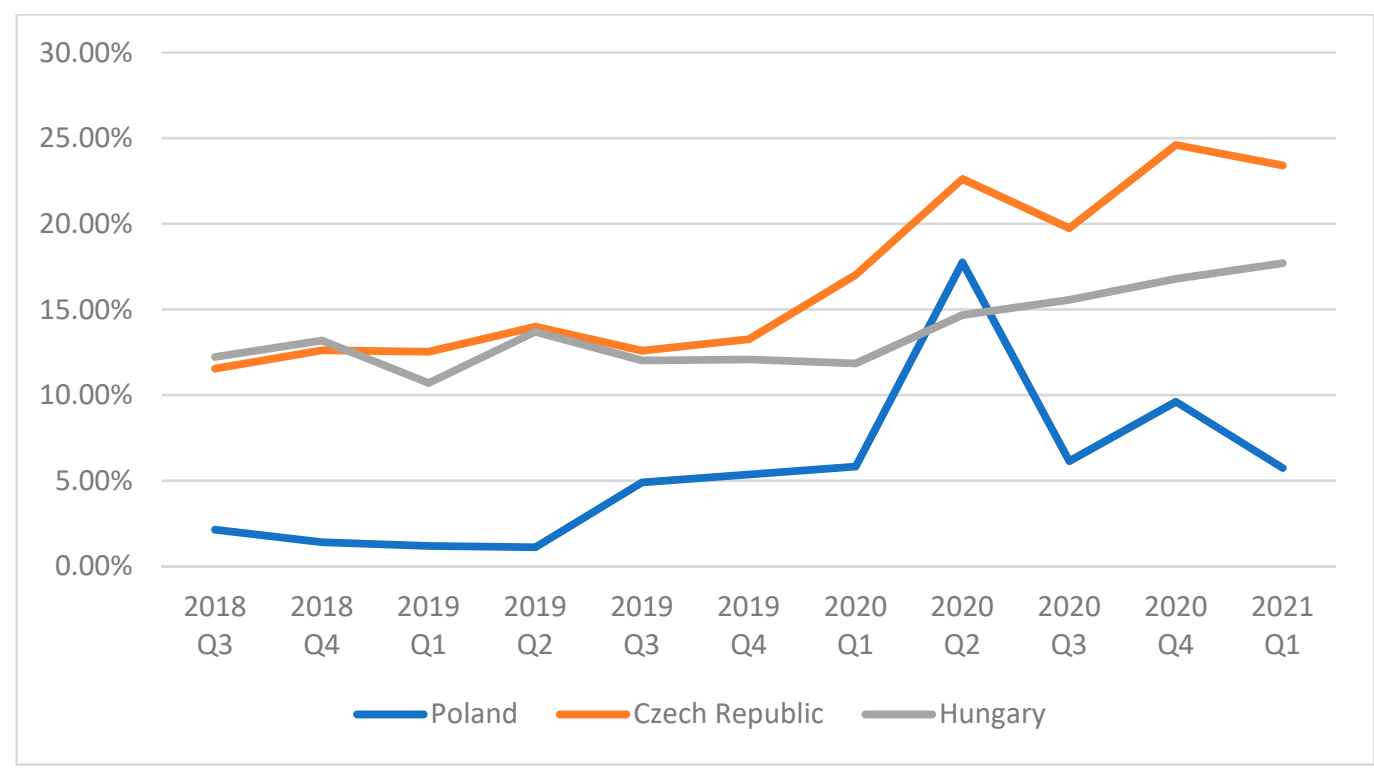

Figure 7. Household saving rate. Lack of sufficient data for Slovakia. Source: (Eurostat Database 2021; OECD Database 2021).

When analyzing changes in the level of household savings in Poland during the pandemic and the lockdowns introduced in connection with it, a sharp increase (as mentioned before) in their level in bank accounts can be noticed, as well as decisions to reduce involve- 
ment in other forms of saving. In March 2020, the monthly increase in the value of deposits amounted to PLN 18.2 billion, while a year earlier in the corresponding month, the value of deposits increased by PLN 7.2 billion. It was only August data that indicated that the monthly increase in the value of deposits was comparable to the increase from the previous year (Janecki 2020). There has therefore been a massive return to cash, typical in periods of crisis, following the shock and unforeseen event of the pandemic and its related lockdown. The data of the National Bank of Poland as well as the research conducted by the Polish Bank Association show that, starting from the first quarter of 2020, the dynamics of the increase in the level of savings on bank accounts of natural persons in Poland compared to 2019 was rather significant (Comiesięczne zestawienie informacji o oszczędnościach 2021, p. 71). On the other hand, a survey conducted in Poland in September 2020 by Consumer Federation and Federation of Financial Market Development showed that the pandemic has drained the savings of 30 percent of households (Figure 8).

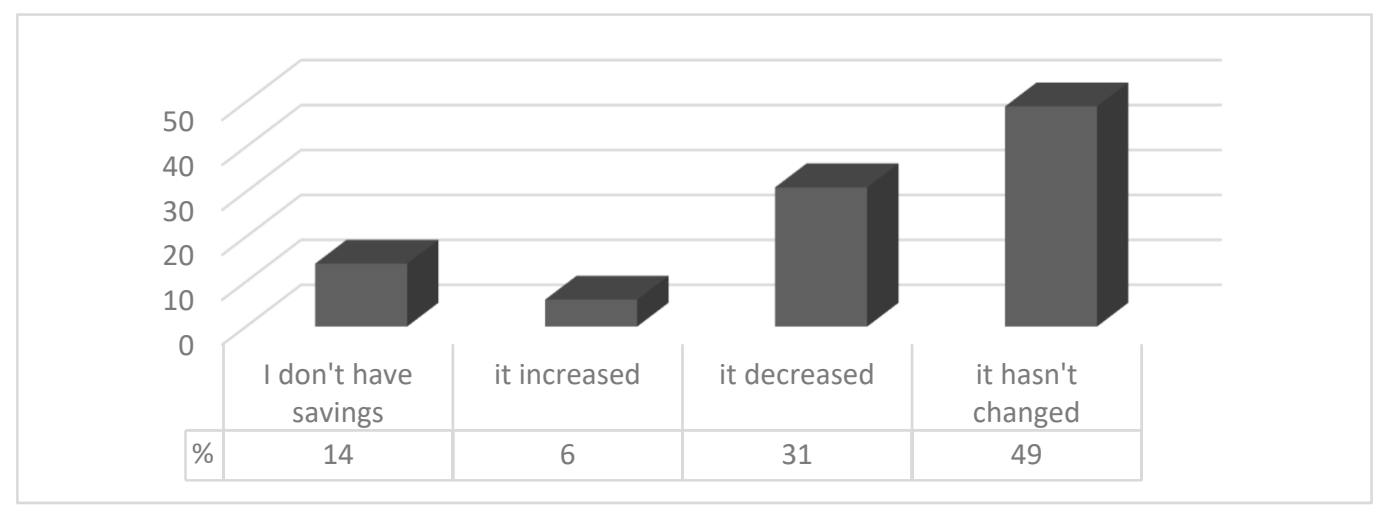

Figure 8. Poles' savings during COVID-19 pandemic-a survey's results. Source: (Finanse Polaków w czasie COVID-19 2020, p. 17).

\section{The Level of Household's Savings and Its Predictors-A Linear Regression Model}

To identify statistically significant predictors that influence the level of savings (HS) expressed as a household gross saving rate, a multiple linear regression was used. The following research question was formulated: Which factors are predictors of the level of household savings? The factors chosen by the authors are:

- The level of unemployment (in \%)-UN,

- Real gross disposable income per capita, growth rate (in \%)-DI,

- Real final consumption expenditure per capita, growth rate (in \%)-FCE,

- Consumer Confidence Index, growth rate (in \%)-CCI,

- The level of gross domestic product (in mln EUR)—GDP.

The data was obtained from the following sources:

- Household gross saving rate (HS)-OECD Database (data from Q3 2018-Q1-2021),

- The level of unemployment (UN)_Eurostat Database, The Central Statistical Office (Poland), Czech Statistical Office, Statistical office of The Slovak Republic and Hungarian Central Statistical Office (data from Q3 2018-Q1 2021),

- Real gross disposable income per capita (DI)_OECD Database (data from Q3 2018-Q1 2021),

- Real final consumption expenditure per capita (FCE) - OECD Database (data from Q3 2018-Q1 2021).

- Consumer Confidence Index (CCI)-OECD Database (data from Q3 2018-Q1-2021),

- The level of gross domestic product (GDP)—Eurostat Database (data from Q3 2018-Q1 2021).

Due to the lack of sufficient quarterly data for Slovakia, this state had to be omitted, so the regression model was built for three remaining CEE states, including Poland, Czech Republic and Hungary. 
The Equation (1) presents the general expression of the multiple regression model.

$$
H S(X)=\beta 0+\beta 1 U N+\beta 2 D I+\beta 3 F C E+\beta 4 C C I+\beta 5 G D P+\varepsilon
$$

The models that resulted from the analysis are presented in Table 3.

Based on results of the regression model, it was found that in Poland in the considered period (Q3 2018-Q1-2021), a gross domestic product (GDP), the level of unemployment (UN) and disposable income (DI) have the highest impact on the level of household savings. What is interesting, in the case of Poland, an increase in GDP results in a decrease in savings. This relation shows that Poles spend their income on consumption more than on savings. In the Czech Republic, two factors are statistically important-Consumer Confidence Index (CCI) and the level of gross domestic product (GDP), both of them having a negative impact on savings (although very limited). In Hungary, the unemployment rate (UN) and gross domestic product (GDP) are statistically significant. When we compare these results to the similar research conducted on the same group of countries by Andrejovská and Buleca (2015), we can see that they are different to a certain extent, although in the model presented in our Article, the set of independent variables is broader.

Table 3. Regression model's final shape.

\begin{tabular}{llc}
\hline \multicolumn{1}{c}{ Country } & \multicolumn{1}{c}{$\begin{array}{c}\text { Statistically Significant } \\
\text { Variables }\end{array}$} & $\begin{array}{c}\text { Estimates of Regression } \\
\text { Coefficients }\end{array}$ \\
\hline \multirow{3}{*}{ Poland $(\mathrm{PL})$} & $\mathrm{UN}(p$ value $=0.00641)$ & $\beta 0=2.507$ \\
& $\mathrm{CCI}(p$ value $=0.0155)$ & $\beta 1=-6.472$ \\
& GDP $(p$ value $=0.01625)$ & $\beta 4=-0.016$ \\
Czech Republic $(\mathrm{CZ})$ & $\mathrm{CCI}(p$ value $=0.000000015)$ & $\beta 5=-0.000004$ \\
& GDP $(p$ value $=0.014625)$ & $\beta 4=-0.023$ \\
& & $\beta 5=-0.0000029$ \\
Hungary $(\mathrm{HU})$ & $\mathrm{UN}(p$ value $=0.00032)$ & $\beta 0=-0.357$ \\
& GDP $(p$ value $=0.02648)$ & $\beta 1=6.008$ \\
& & $\beta 4=0.00000747$ \\
\hline
\end{tabular}

Source: own work.

The regression models that were built in this study are characterized by the high level of the adjusted $\mathrm{R}^{2}$, which takes the following values: 0.83 (Poland), 0.98 (Czech Republic) and 0.87 (Hungary), so they can be used in analyses and forecasts. However, the authors would like to point out that a certain disadvantage of the models presented in the paper is the fact that the data used for their construction are quarterly and come from a rather short period of time (Q3 2018-Q1 2021), which means that not all variables are characterized by a sufficiently high level of the coefficient of variation, because at such short intervals the data do not always change significantly (it can be seen, e.g., in the level of GDP and disposable income).

\section{Conclusions: The Assessment Is Ambiguous}

The issue discussed in this article is extremely important from the point of view of assessing the financial situation of households during the pandemic. It is a consequence of the analysis of channels through which this crisis affects the household in general. The current pandemic has resulted in unprecedented actions on the national and international level, which resulted in, inter alia, closing economies on an unparalleled scale. The economic costs are borne by all entities of the national economy, including households that found themselves in a specific situation as a result of the pandemic. Downtime in the functioning of enterprises, and even entire industries, results in a reduction of job vacancies, a deep lockdown also limits the demand for goods and services.

The assessment of the future economic and financial situation, the effect of which are specific economic decisions made by households, is also of significant importance. The 
research has shown that an assessment of the financial situation of households in terms of savings level is ambiguous. Kansiime et al. (2021) indicate that the assessment of the financial situation of households depends largely on its reference point. In Europe, it is of course, despite the effects of the pandemic, very good, when compared, for example, to East Africa, where the degree of poverty and food insecurity was enormous even before the pandemic, which was caused by concurrent crises (desert locust invasions or extreme weather conditions). This situation is currently exacerbated by the pandemic and its consequences. It is obvious that the pandemic induced concerns about financial security, which may result in increase in savings, including bank deposits. The research conducted in the USA showed that higher infection rates are positively related with the levels of bank deposits (Levine et al. 2020, p. 2). In Poland, the results of research conducted by various institutions are ambiguous in this particular matter. They show, however, that most Poles are doing well financially and do not complain about the condition of their household budget during COVID-19, but the pandemic has depleted some of them. The reason why the savings are melting, could therefore be reluctance of Poles to incur debt in times of economic uncertainty and thus a greater tendency to breach their savings than to use a loan or a loan to finance larger purchases. It cannot be ruled out that in this way the respondents tried to compensate for lower income during the lockdown or even for their complete loss.

On the other hand, an important question arises: did the COVID-19 pandemic trigger the need for households to increase the level of credits and loans? It's obvious that the uncertainty caused by the epidemic and economic situation limits not only the level of consumption, but also the scale of Poles' indebtedness. It is also worth paying attention to the fact that the funds from credits and loans are not so much used by Poles to fill the gap in the household budget, as to finance larger expenses which they are unable to cover with their own funds.

The authors take into account the fact that this study has limitations. They are, i.a., a consequence of the fact that not all data are available for quarterly and shorter periods, and taking into account the volatility of economic conditions, due to the rapid spread of the virus and its impact on the economy in the short term, the lack of such data does not always allow for a proper assessment of the analyzed phenomenon. This also applies to the relevance of the regression model built for the purpose of this article. Due to this fact the research will be continued in order to propose a measure that will enable the evaluation of the financial well-being, as proposed by, i.a., the Consumer Financial Protection Bureau (Consumer Financial Protection Bureau 2015). In this particular context, it is important to notice that because there is no single definition of a household's financial well-being, and different aspects can be taken into account in order to assess it, one should decide what are the most important aspects in this particular area. One of the most important factors (especially in the COVID-19 case and other possible pandemics) may be the ability to absorb a financial shock that may arise as a result of such events. The results of surveys presented in this article may then be compared to the results of such research in order to point out some issues that are of a great importance in terms of the assessment of financial well-being.

On the other hand, the authors will take into account the possibility of building a more complex model in which the household's financial outcome can be treated as a dependent variable. Among independent variables, a different set of measures can be applied (from those discussed in this article) with the possibility to include a so-called financial hardship, which is understood as an experience of financial shocks (Collins and Urban 2019, p. 10). The last outcome is especially important in terms of COVID-19 pandemics, because it is directly related to it.

The authors believe that expanding the research and applying more sophisticated statistical and econometric methods will contribute to a better understanding of the factors influencing the assessment of the situation of households during and after the pandemic.

Author Contributions: Conceptualization, G.S., W.G., Ł.S., methodology, G.S., W.G., Ł.S.; formal analysis, G.S., W.G.; investigation, G.S., W.G., Ł.S., resources, G.S., W.G., Ł.S.; data curation, G.S., W.G.; 
writing-original draft preparation, G.S., W.G., Ł.S.; writing—review and editing, Ł.S.; visualization, G.S., W.G., Ł.S.; supervision, G.S.; project administration, G.S.; funding acquisition, G.S. All authors have read and agreed to the published version of the manuscript.

Funding: This research received no external funding.

Institutional Review Board Statement: Not applicable.

Informed Consent Statement: Not applicable.

Data Availability Statement: Not applicable.

Conflicts of Interest: The authors declare no conflict of interest.

\section{References}

Andrejovská, Alena, and Ján Buleca. 2015. Regression Analysis of Factors Influencing Volume of Households' savings in the V4 Countries. Mediterranean Journal of Social Sciences 7: 213. [CrossRef]

Anna Unton. 2020. Mapa biedy i bogactwa. Tak wyglądamy na tle Europy (Map of Poverty and Wealth. This Is What We Look Like Compared to Europe). Available online: https:/ / www.money.pl/gospodarka/mapa-zarobkow-tak-wygladamy-na-tle-europy6572025341844160a.html (accessed on 16 April 2021).

Anna Unton. 2021. Najniższe bezrobocie to tylko jedna strona medalu. Gorzej jest z szukaniem pracy. Jesteśmy w ogonie UE (The Lowest Unemployment Rate Is Only One Side of the Coin. It Is Worse with Looking for a Job. We Are in the Tail of the EU). Available online: https:/ / www.money.pl/gospodarka/najnizsze-bezrobocie-to-tylko-jedna-strona-medalu-gorzej-jest-zszukaniem-pracy-jestesmy-w-ogonie-ue-6619792698981024a.html (accessed on 22 March 2021).

Barrafrem, Kinga, Daniel Västfjäll, and Gustav Tinghög. 2020. Financial well-being, COVID-19, and the financial better-than-averageeffect. Journal of Behavioral and Experimental Finance 28: 100410. [CrossRef] [PubMed]

Bilyk, Olga, Anson T. Y. Ho, Mikael Khan, and Geneviève Vallée. 2020. Household Indebtedness Risks in the Wake of COVID-19. Available online: https:/ / www.bankofcanada.ca/2020/06/staff-analytical-note-2020-8/ (accessed on 3 May 2021).

Boissay, Frédéric, Daniel Rees, and Phurichai Rungcharoenkitkul. 2020. Dealing with Covid-19: Understanding the Policy Choices. Basel: Bank for International Settlements.

Brobeck, Stephen James. 2008. Understanding the Emergency Savings Needs of Low and Moderate-Income Households: A Survey Based Analysis of Impacts, Causes and Remedies. Washington, DC: Consumer Federation of America.

Carbone, Enrica, and John Hey. 1999. The Effect of Unemployment on Saving: An Experimental Analysis. Available online: https:/ / www.researchgate.net/publication/228494796 (accessed on 1 August 2021).

Chetty, Raj, John Friedman, Nathaniel Hendren, Michael Stepner, and The Opportunity Insights Team. 2020. The Economic Impacts of Covid-19: Evidence from a New Public Database Built Using Private Sector Data. Available online: https: / / opportunityinsights. org/wp-content/uploads/2020/05/tracker_paper.pdf (accessed on 23 April 2021).

Collins, J. Michael, and Carly Urban. 2019. Measuring Financial Well-being Over the Lifecourse. European Journal of Finance 26: 341-59. [CrossRef]

Comiesięczne zestawienie informacji o oszczędnościach (Monthly Information on Savings). 2021. Warsaw: Polski Fundusz Rozwoju.

Consumer Financial Protection Bureau. 2015. Measuring Financial Well-Being: A Guide to Using the CFPB Financial Well-Being Scale. Available online: https:/ files.consumerfinance.gov/f/201512_cfpb_financialwell-being-user-guide-scale.pdf (accessed on 30 June 2021).

Cooper, Cheryl R., Maura Mullins, and Lida R. Weinstock. 2020. Covid-19: Household Debt during the Pandemic. Available online: https:/ / www.everycrsreport.com/reports/R46578.html (accessed on 30 June 2021).

Dolan, Paul, Tessa Peasgood, and Mathew White. 2008. Do we really know what makes us happy? A review of the economic literature on the factors associated with subjective well-being. Journal of Economic Psychology 29: 94-122. [CrossRef]

Duszyński, Jerzego, Aneta Afelt, Anna Ochab-Marcinek, Radosław Owczuk, Krzysztof Pyrć, Magdalena Rosińska, Andrzej Rychard, and Tomasz Smiatacz. 2020. Zrozumieć COVID-19 (To Understand COVID-19). Warszawa: Polska Akademia Nauk.

Edukacjagieldowa.pl. 2020. Available online: https:/ / www.edukacjagieldowa.pl/2020/10/koronawirus-w-nierownomierny-sposobwplywa-na-oszczedwww.edukacjagieldowa.plnosci/ (accessed on 15 April 2021).

Eurostat Database. 2021. Available online: https:/ / ec.europa.eu/eurostat (accessed on 20 August 2021).

Finanse Polaków w czasie COVID-19 (Poles' finances during COVID-19). 2020. Federacja Konsumentów. Warszawa: Fundacja Rozwoju Rynku Kapitałowego.

Fox, Jonathan, and Suzanne Bartholomae. 2020. Household finances, financial planning, and COVID-19. Financial Planning Review 3: e1103. [CrossRef]

Gerrans, Paul, Craig Speelman, and Guillermo Campitelli. 2014. The Relationship Between Personal Financial Wellness and Financial Wellbeing: A Structural Equation Modelling Approach. Journal of Family and Economic Issues 35: 145-60. [CrossRef]

GfK Purchasing Power Europe. 2020. Free Compendium for All 42 European Countries. Available online: https://insights.gfk.com/ gfk-purchasing-power-europe-2020-download-compendium (accessed on 16 April 2021). 
Gliński, Zdzisław, and Andrzej Żmuda. 2020. Epidemia i pandemie chorób zakaźnych (Epidemics and Pandemics of Infectious Diseases), Życie weterynaryjne no 95. Available online: https://www.vetpol.org.pl/dmdocuments/ZW-09-2020-02.pdf (accessed on 2 April 2021).

Grzeszak, Jacek, Filip Leśniewicz, and Paweł Śliwowski. 2020. Pandemics. Zestaw Narzędzi Fiskalnych i Monetarnych w Czasach Kryzysu (Pandemics. A Set of Fiscal and Monetary Tools in Times of Crisis). Warszawa: Polski Instytut Wydawniczy.

Janecki, Jarosław. 2020. Wymuszone Oszczędności w Okresie Pandemii (Forced Savings during a Pandemic). Available online: https:/ / www.obserwatorfinansowy.pl/bez-kategorii/rotator/wymuszone-oszczednosci-w-okresie-pandemii/ (accessed on 2 May 2021).

Jerusalmy, Olivier. 2020. Coronavirus: A Dangerous Wave of Personal Over-Indebtedness Is on Its Way: Here Is How to Avoid It. Available online: https: / www.finance-watch.org/ coronavirus-a-dangerous-wave-of-personal-over-indebtedness-is-on-itsway-here-is-how-to-avoid-it/ (accessed on 2 May 2021).

Kahneman, Daniel, and Alan B. Krueger. 2006. Developments in the measurement of subjective well-being. Journal of Economic Perspectives 20: 3-24. [CrossRef]

Kansiime, Monica K., Justice A. Tambo, Idah Mugambi, Mary Bundi, Augustine Kara, and Charles Owuor. 2021. COVID-19 implications on household income and food security in Kenyaand Uganda: Findings from a rapid assessment. World Development 137: 105199. [CrossRef] [PubMed]

Kłopocka, Aneta Maria, Tomasz Kopczyński, and Grażyna Lenicka-Bajer. 2014. Financial Situation and Attitudes towards Saving in Polish Society: Evidence from Micro-Data. Annals of the Economy Series. Special Volume. Târgu Jiu: Constantin Brâncuşi” University of Târgu Jiu.

Kłopocka, Aneta Maria. 2016. Does Consumer Confidence Forecast Household Saving and Borrowing Behavior? Evidence for Poland 133: 693-717. Available online: https://link.springer.com/content/pdf/10.1007/s11205-016-1376-4.pdf (accessed on 7 August 2021).

Kosny, Marek, and Maria Piotrowska. 2013. Economic Security of Households and Their Savings and Credits. National Bank of Poland Working Paper no. 146. Warsaw: National Bank of Poland.

Kurowski, Łukasz. 2021. Household's Overindebtedness during the COVID-19 Crisis: The Role of Debt and Financial Literacy. Risks 9: 62. [CrossRef]

Levine, Ross, Chen Lin, Mingzhu Tai, and Wensi Xie. 2020. How Did Depositors Respond to COVID-19? The Review of Financial Studies, hhab062. [CrossRef]

Marcinkowska, Monika. 2020. Kapitał Relacyjny Banków a Kryzys Pandemiczny. Działania Polskich Banków Względem Interesariuszy w obliczu COVID-19 (Banks' Relational Capital and the Pandemic Crisis. Actions of Polish Banks towards Stakeholders in the Face of COVID-19). Łódź: Wydawnictwo SIZ.

Muranyi, Thomas, and Julia Richter. 2020. Europeans Have around $€ 773$ Less in 2020 Due to COVID-19. GfK, October 20.

OECD Database. 2021. Available online: Data.oecd.org (accessed on 20 May 2021).

Pogorzelski, Karol. 2020. Wptyw Covid-19 na finanse osobiste Polaków oraz mieszkańców Europy (The Impact of Covid-19 on the Personal Finances of Poles and European Citizens). Amsterdam: ING Bank.

Raport Banku Pekao. 2020. Gospodarka w czasach pandemii. Spojrzenie sektorowe na bazie pierwszych doświadczeń globalnych" (Pekao Bank Report "Economy in a Pandemic. Sectoral View Based on the First Global Experiences"). Available online: https:/ / www.pekao.com.pl/o-banku/aktualnosci/084c4abc-018b-4af4-bb32-ee1c44236326/raport-banku-pekaogospodarka-w-czasach-pandemii-spojrzenie-sektorowe-na-bazie-pierwszych-doswiadczen-globalnych.html (accessed on 27 April 2021).

Rozporządzenie Ministra Zdrowia. 2020. Rozporządzenie Ministra Zdrowia z dnia 20 marca 2020 r. w sprawie ogłoszenia na obszarze rzeczypospolitej polskiej stanu epidemii (Regulation of the Minister of Health of March 20. 2020 on the declaration of an epidemic in the territory of the Republic of Poland) (Dz. U. z 2020 r., poz. 433). Available online: https://isap.sejm.gov.pl/isap.nsf/ DocDetails.xsp?id=WDU20200000491 (accessed on 30 June 2021).

Suomi, Aino, Timothy P. Schofield, and Peter Butterworth. 2020. Unemployment, Employability and COVID19: How the Global Socioeconomic Shock Challenged Negative Perceptions Toward the Less Fortunate in the Australian Context. Frontiers in Psychology 11: 2745. Available online: https:/ / www.frontiersin.org/articles/10.3389/fpsyg.2020.594837/full\#B10 (accessed on 14 April 2021). [CrossRef] [PubMed]

Ventura, Luca. 2020. Unemployment Rates Around the World 2020, Global Finance, 22 October. Available online: https://www.gfmag. com/global-data/economic-data/worlds-unemployment-ratescom (accessed on 16 April 2021).

WHO Announces a Pandemic. 2020. Available online: https://www.euro.who.int/en/health-topics/health-emergencies/coronaviruscovid-19/news/news/2020/3/who-announces-covid-19-outbreak-a-pandemic (accessed on 20 April 2021). 